Volume 4 No. 1, Juni 2019

P ISSN 2442-594X | E ISSN 2579-5708

http://journal.iainlangsa.ac.id/index.php/tibyan

DOI: $10.32505 /$ tibyan.v4i1.883

\title{
KEPEMIMPINAN PERSPEKTIF ALQURAN; INTERPRETASI SEMIOTIK QS. AL-BAQARAH (2): 30-34
}

Leadership of The Qur'anic's perspectives; Semiotic's Interpretation Of The Surah AlBaqarah (2): 30-34

\author{
Azhari Andi \\ UIN Sunan Kalijaga Yogyakarta \\ azhariandi59@gmail.com
}

\begin{abstract}
This article discusses about leadership on QS. Al-Baqarah (2): 30-34. The Article analyzes the verses through semiotic perspective which is introduced by Charles Sander Pierce. The article finds some factors that are frequently used to measure a leader; spiritual piety, ancestry, and capacity of knowledge. Alqur'an criticizes measuring a leader by spiritual piety only and ancestry. Furthermore, Alqur'an cites that capacity of knowledge is more important than piety and ancestral factor to measure the leader.
\end{abstract}

Keywords: Alqur'an, Leadersip, Caliph, Semiotic and Adam

\begin{abstract}
Abstrak
Tulisan ini membicarakan tentang isu kepemimpinan dalam QS. Al-Baqarah (2): 30-34. Data-data dalam tulisan ini akan dianalisis dengan pendekatan Semiotika Charles Sanders Pierce. Artikel ini mengemukakan beberapa faktor yang acap kali dijadikan tolak ukur menjadi seorang pemimpin, yakni kesalehan spiritual, keturunan nasab dan kapasitas pengetahuan. Menurut Alqur'an, kepemimpinan bukanlah tentang seberapa saleh atau berasal dari keturunan darah biru atau bangsawan, namun lebih kepada siapa yang mempunyai kapsitas (pengetahuan) untuk menjadi pemimpin tanpa mempedulikan asal-usul keturunannya.
\end{abstract}

Kata Kunci: Alqur'an, Kepemimpinan, Khalifah, Semiotika dan Adam 


\section{Pendahuluan}

Isu kepemimpinan merupakan diskursus yang selalu aktual dan relevan untuk diperbincangkan. Sebab, kepemimpinan adalah sebuah keniscayaan bagi masyarakat yang tergabung dalam sebuah komunitas baik dalam skala kecil maupun dalam skala besar. Sejarah mencatat bahwa isu kepemimpinan pada hakekatnya telah muncul sejak era awal Islam. ${ }^{1}$ Hal ini dapat dilihat dari persoalan yang diperselisihkan setelah wafatnya nabi, tidak lain adalah problem kepemimpinan. ${ }^{2}$ Sebelum Islam datang di tanah Arab, isu kepemimpinan telah eksis sebagaimana dijumpai pada kasus penguasapenguasa suku yang ada di Arab pada waktu itu, sebut saja Bani Quraisy, Bani Hasyim dan lain-lain. Bahkan ratusan abad sebelum itu, tepatnya pada masa Nabi Isa (Yesus), sejarah juga telah mengabadikan adanya isu kepemimpinan melalui nama-nama penguasa kala itu, seperti Pontius Pilatus, Heredos dan Imam Besar Kayafas. ${ }^{3}$ Atas dasar itu, tidak berlebihan jika menyatakan bahwa diskursus kepemimpinan merupakan isu yang selalu aktual dan faktual, bakan Islam tidak ketinggalan dalam menyoroti isu ini.

Dalam Islam, diskursus kepemimpinan menempati posisi yang penting. Hal ini bisa dilihat dari seringnya Alqur'an berbicara tentang tema ini di berbagai ayat dan surat. Alqur'an sering menampilkan berbagai kisah pemimpin dan kepemimpinannya, seperti kisah Ratu Balqis, Nabi Sulaiman, Fir'aun dan Nabi Musa, Nabi Yusuf, Raja Zulkarnain dan kisah lainnya. Selain itu, Alqur'an juga menggunakan term-term tertentu untuk menjelaskan isu kepemimpinan, sepeti term khalifah, wali, sulthān dan hākim, auliyā', imām dan sebagainya. Di antara isu kepemimpinan yang disuguhkan Alqur' an adalah term khalifah pada kisah Adam dalam QS. Al-Baqarah (2): 30-34.

Kisah Adam dalam QS. Al-Baqarah (2): 30-34 secara eksplisit menyebutkan term Khalifah. Imam al-Thabari menjelaskan bahwa term khalifah pada ayat tersebut memiliki arti pemimpin. ${ }^{4}$ Kisah kepemimpinan Adam semakin menarik, karena dipresentasikan dalam bentuk kisah dengan dialog antara Tuhan, malaikat, Iblis dan Adam sendiri. Dialog antara Tuhan, malaikat, Iblis dan Adam, jika dilihat dari perspektif semiotika, mengandung banyak "tanda" yang perlu dikaji dan ditelusuri lebih jauh. Misalnya, ketika Allah mengutarakan keinginanya kepada malaikat dengan berfirman "Aku hendak menjadikan khalifah di muka bumi", maka para laikat merespon dengan nada :protes" "apakah Engkau hendak menjadikan makhluk yang suka berbuat kerusakan dan melakukan pertumpahan darah di muka bumi? padahal kami senantiasa bertasbih dan memuji mu”. Ungkapan malaikat merupakan sign (tanda) yang menyiratkan makna yang signifikan.

\footnotetext{
${ }^{1}$ Khalid Ibrahim Jindan, Teori Pemerintahan Islam Menurut Ibnu Taimiyah (Jakarta: Rineka Cipta, 1994), h. V

${ }^{2}$ Khalid Ibrahim Jindan, Teori Pemerintahan Islam Menurut Ibnu Taimiyah (Jakarta: Rineka Cipta, 1994), h. V

${ }^{3}$ Yahya Wijaya, "Kepemimpinan Yesus sebagai Acuan Bagi Kepemimpinan Gereja Masa Kini" dalam Jurnal Jaffray, vol. 2, no. 16, 2018, h. 134

${ }^{4}$ Al-Thabarì, Jāmi al-Bayān fì Ta’wìl al-Qur'ān, juz. 1, h. 449
} 
Apakah makna ungkapan malaikat tersebut dan makna tanda-tanda lain, dalam kaitannya dengan isu kepemimpinan, pada kisah Adam QS. Al-Baqarah 2/30-34? Artikel ini akan mengupas pertanyaan tersebut dengan perspektif semiotika Charles Sanders Pierce. Sebab dengan pendekatan semiotika, ${ }^{5}$ tanda-tanda yang dirpoduksi dalam teks (kisah) dapat diketahui maknanya sehingga melahirkan interpretasi baru tentang kisah Adam dan kaitannya dengan isu kepemimpinan.

\section{Metodologi}

Kisah Adam dalam QS. Al-Baqarah (2): 30-34 akan dikaji dari perspektif semiotika yang digagas oleh Charles Sanders Pierce. Semiotika merupakan disiplin ilmu linguistik yang concern membahas makna (meaning) dari tanda (sign). Termasuk dalam tanda adalah bahasa, mitos, kesenian dan ritual keagamaan. ${ }^{6}$ Dalam semiotika Pierce, tanda selalu memiliki tiga dimensi yang saling berkelindan, (1) Representamen (R) merupakan sebuah fenomena yang dapat dianggap sebagai representasi karena sifat potensialnya untuk menjadi tanda. Tanda-tanda dapat berupa iconic, indexial dan symbolic; (2) Objek (O) adalah sesuatu yang mengacu kepada hal lain; dan (3) interpretan (I) yaitu sesuatu yang dapat diinterpretasi sebagai buah dari pemikiran yang dapat digeneralisasi dari dua term lain (representamen dan objek). ${ }^{7}$ Dalam istilah lain, ketiga unsur semiotika Pierce juga disebut dengan segitiga triadic. Menurut Pierce, Interpretan (I) tidak tunggal dan bisa terus berkembang sehingga melahirkan interpretasi tanpa batas. Perlu dicatat bahwa dalam membaca kisah Adam sebagai khalifah pada QS. Al-Baqarah (2): 30-34, penulis membatasi penggunaan teori semiotika Pierce pada aplikasi triadic di atas.

\section{Khalifah dalam Alquran}

Sebelum membaca kisah penciptaan Adam sebagai khalifah dari sudut pandang semiotika Pierce, konsep atau pengetian khalifah itu sendiri perlu diketengahkan agar diperoleh pondasi yang kuat tentang manka khalifah. Secara etimologi, khalifah berasal dari khalafa-yakhlifu yang berarti mengganti (al-badl). Pelaku (fa'il) dari khalafa_yaitu khalifah/ khulafá' yang memiliki arti pengganti, penguasa. ${ }^{8}$ Term khalifah diartikan pengganti karena orang yang menggantikan bertugas untuk menjalankan tugas atas nama orang yang digantikan baik orang yang diganti ada bersamanya atau tidak. ${ }^{9}$ Dengan demikian, term khalifah cukup tepat dikaitan dengan diskursus kepemimpinan.

\footnotetext{
${ }^{5}$ Untuk informasi lebih lanjut tentang semiotika bisa merujuk buku Aart Van Zeost, Semiotika; tentang Tanda- Cara Kerjanya dan Apa yang Kita Lakukan dengannya, Terj. Ani Soekowati (Jakarta: Yayasan Sumber Agung, 1993)

${ }^{6}$ Wildan Taufiq, Semiotika untuk Kajian Sastra dan Alqur'an, (Bnadung: Yrama Widya, 2016), h. ii h. 30-38

${ }^{7}$ Wildan Taufiq, Semiotika untuk Kajian Sastra dan Alqur'an, (Bnadung: Yrama Widya, 2016),

${ }^{8}$ Al-Misri, Lisān al-'Arab (Beirut: Dār al-Shadr, 1992), juz. IX, h. 82-83

${ }^{9}$ Raghib al-Ashfihani, Mu’jam Mufradāt al-Qur'ān, h. 157
} 
Term khalifah dan derivasinya, dalam Alqur'an, terulang sebanyak 127 kali. $^{10}$ Alqur'an menyebutkan term khalifah sebanyak 2 kali dalam bentuk tunggal (singular) dan 3 kali dalam bentuk plural (jama'). ${ }^{11}$ Berikut beberapa ayat Alqur'an yang menyebutkan term khalifah dan khulafá' beserta penjabaran singkat tentang tafsirnya,

QS. Al-Baqarah (2): 30

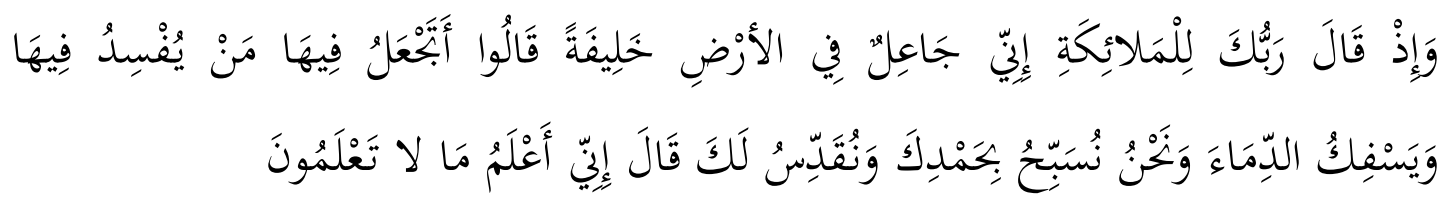

Terjemah: "Ingatlah ketika Tuhanmu berfirman kepada para malaikat: "Sesungguhnya Aku hendak menjadikan seorang khalifah di muka bumi". Mereka berkata: "Mengapa Engkau hendak menjadikan (khalifah) di bumi itu orang yang akan membuat kerusakan padanya dan menumpahkan darah, padahal kami senantiasa bertasbih dengan memuji Engkau dan menyucikan Engkau?" Tuhan berfirman: "Sesungguhnya Aku mengetahui apa yang tidak kamu ketahui".(Q.S Al Baqarah (2): 30)

Term khalifah dalam ayat di atas berkaitan dengan dialog Tuhan dengan malaikat tentang rencana Tuhan menjadikan Adam sebagai khalifah di muka bumi. Imam al-Thabari, mufassir kenamaan klasik, menjelaskan bahwa term khalifah dalam ayat di atas berasal dari perkataan

$$
\text { خلف فلان فلانًا في هذا الأمر، إذا قام مقامه فيه بعده }
$$

Fulan menggantikan fulan lain dalam sebuah urusan, karena ia menggantikan posisi orang yang digantikan, ${ }^{12}$ sebagaimana dapat ditemukan dalam QS. Yunus 14.

Imam al-Thabari juga menambahkan penjelasan lebih rinci tentang makna khalifah dalam ayat tersebut dengan mengutip riwayat dari Ibnu Ishāq. Ibnu Ishāq menyebutkan bahwa makna khalifah dalam ayat tersebut adalah Allah hendak menjadikan Adam sebagai penghuni bumi dan memakmurkannya sekaligus sebagai pemimpin, dan tidak termasuk dari golongan kalian (malaikat). ${ }^{13}$ Senada dengan Imam al-Thabari, Imam Ibnu Katsīr, mufassir fenomenal abad pertengahan, juga menjelaskan

${ }^{10}$ Muhammad Fuad Abd al-Baqi, Mu’jam Mufahras li Alfadz Alqur'an (Indonesia: Maktabah Dakhlan, t.th), h. 303. Lihat juga Abd Rahim, "Khilafah dan Khalifah dalam Alqur'an" dalam Hunafa; Jurnal Studi Islamika, vol. 9, no. 1, juni 2012, h. 22-23

${ }^{11}$ M. Quraish Shihab, Membumikan Alqur'an; Fungsi dan Peran Wahyu dalam Kehidupan Masyarakat (Bandung: Mizan, cet. III, 2009), h. 243

${ }^{12}$ Al-Tthabari, Jami al-Bayan fi Ta'wil Alqur'an (Beirut: Muassasah al-Risalah, 1420 H/ 2000 M), juz. 1, h. 449

${ }^{13}$ Al-Thabarì, Jāmi al-Bayān fì Ta'wìl al-Qur'ān, juz. 1, h. 449 
bahwa khalifah adalah orang yeng menggantikan sebagian mereka dalam urusan. ${ }^{14}$ Imam Thabari dan Imam Ibnu Katsīr menyertakan riwayat Ibnu 'Abbās yang menjelaskan bahwa yang dimaksud dengan khalifah sebagai pengganti adalah pengganti Allah dalam menegakkan hukum di muka bumi. ${ }^{15}$

Imam al-Thabari menyebutkan secara jelas bahwa khalifah dalam QS. AlBaqarah (2): 30 mengandung pengertian sebagai seorang pemimpin yang memiliki tugas antara lain menempati dan memakmurkan bumi serta sebagai pengganti Allah dalam urusan menegakkan hukum di bumi. Atas dasar itu, term khalifah dapat disejajarkan dengan term pemimpin.

QS. Shād (38); 26

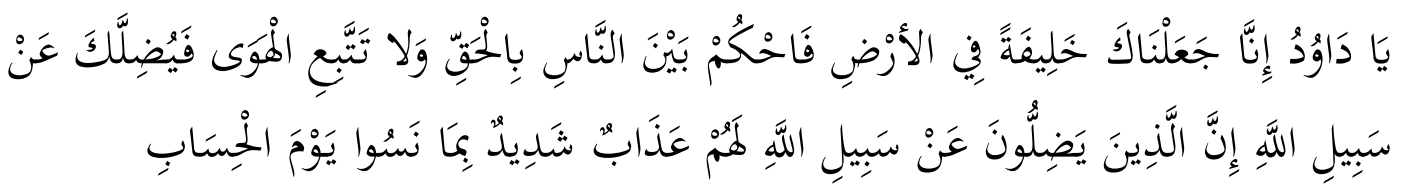

Terjemah: "Hai Daud, sesungguhnya Kami menjadikan kamu khalifah (penguasa) di muka bumi, maka berilah keputusan (perkara) di antara manusia dengan adil dan janganlah kamu mengikuti hawa nafsu, karena ia akan menyesatkan kamu dari jalan Allah. Sesungguhnya orang-orang yang sesat dari jalan Allah akan mendapat azab yang berat, karena mereka melupakan hari perhitungan" (QS. Sad (38): 26).

Ayat ini merupakan dialog Allah dengan kekasihnya Nabi Daud. Allah telah menjadikan nabi Daud sebagai khalifah. Mengenai term khalifah dalam ayat ini, Imam al-Qurtubi mengimentari bahwa khalifah yang dimaksud adalah Nabi Daud yang menggantikan kepemimpinan para nabi, pemimpin-pemimpin shaleh terdahulu yang datang sebelum Nabi Daud. Sebagai pemimpin, Nabi Daud mendapat mandat untuk memerintahkan manusia kepada kebaikan dan mencegah dari perbuatan mungkar. ${ }^{16}$ Senada dengan Imam al-Qurtubi, imam Al-Thabrāni juga mejelaskan bahwa yang dimaksud dengan khalifah dalam ayat tersebut adalah والخليفةُ هو المدبرُ للأمرِ والمقيم (penguasa yang mengatur urusan manusia). ${ }^{17}$ Buya Hamka dalam tafsirnya juga menerangkan bahwa Nabi Daud adalah khalifah Allah, yakni pengganti Allah untuk melaksanakan hukum Tuhan dalam pemerintahannya. Lebih lanjut, Hamka menerangkan bahwa khalifah pada ayat di atas juga bisa diartikan bahwa Nabi Daud adalah pengganti dari raja-raja, pemimpin-pemimpin dan nabi-nabi Bani Isra'il terdahulu. ${ }^{18}$

\footnotetext{
${ }^{14}$ Ibnu Katsìr, Tafsìr al-Qur'ān al- ‘Azïm (tt: Dar Thayyibah, 1420 H/ 1999 M), juz. 1, h. 218

${ }^{15}$ Al-Tthabari, Jāmi al-Bayān fi Ta'wìl al-Qur'ān, juz. 1, h. 453. Lihat juga Ibnu Katsìr, Tafsìr alQur'ān al-'Azïm (tt: Dar Thayyibah, 1420 H/ 1999 M), juz. 1, h. 218

${ }^{16}$ Al-Qurtūbi, al-Jāmi' li Ahkām Alqur'ān (Kairo: Dār al-Kutub al-Mishriyyah, 1286 H/ 1964 M), juz. 15, h. 188

${ }^{17}$ Lihat juga Jalaludin al-Mahalli dan Jalāl al-Dīn al-Suyūthi, Tafsìr al-Jalālain, terj. Bahrun Abubakar (Banudng: Sinar Baru Algensindo, cet. II 2004), h. 656

${ }^{18}$ Hamka, Tafsir al-Azhar (Jakarta: Pustaka Panjimas, 1982), juz. I, h. 167
} 
Uraian para pakar tafsir di atas dirasa cukup untuk menyatakan bahwa term khalifah mempunyai arti pemimpin. Sang khalifah adalah pengganti dari pemimpinpemimpin sebelumnya untuk menjalankan tugas dan mengatur pemerintahan dengan menegakkan hukum Tuhan.

QS. Al-A'rāf (7): 69

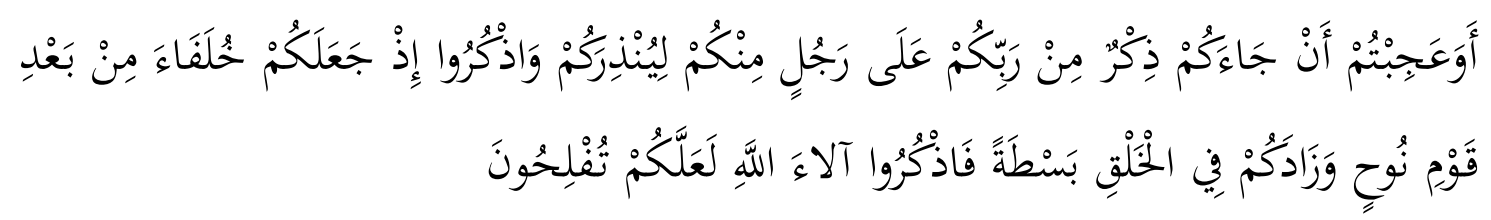

Terjemah: "Apakah kamu (tidak percaya) dan heran bahwa datang kepadamu peringatan dari Tuhanmu yang dibawa oleh seorang laki-laki di antaramu untuk memberi peringatan kepadamu? Dan ingatlah oleh kamu sekalian di waktu Allah menjadikan kamu sebagai pengganti-pengganti (yang berkuasa) sesudah lenyapnya kaum Nuh, dan Tuhan telah melebihkan kekuatan tubuh dan perawakanmu (daripada kaum Nuh itu). Maka ingatlah nikmat-nikmat Allah supaya kamu mendapat keberuntungan." (QS. Al-‘Araf (7): 69).

Kata khulafã' dalam ayat di atas merupakan bentuk jama' dari khalifah sebagaimana dijelaskan oleh Ibnu Atiyyah, dalam al-Muharrar al-Wajiz, dengan mengutip sebuah nasyid dari Ibnu Ali berikut ini,

$$
\begin{aligned}
& \text { جمع خليف كظريف وظرفاء ، وخليفة جمع خلائف والعرب تقول خليفة وخليف ، وأنشد أبو علي : } \\
& \text { فإن يزل زائل يوجد خليفته ... وما خليف أبي وهب بموجود19 }
\end{aligned}
$$

"Jika ada yang hilang, maka aka nada penggantinya. Dan tidak ada pengganti Abi Wahab".

Ibnu 'Atiyyah mengungkapkan bahwa kata khalifah memiliki arti sebagai pengganti. Senada dengan Ibnu 'Atiyah, Imam Ibnu 'Asyūr mefasirkan term khalifah, dalam ayat tersebut, sebagai pemimpin yang mengantikan orang lain dalam mengurusi suatu urusan atau perkara. Ibnu 'Asyūr menulis,

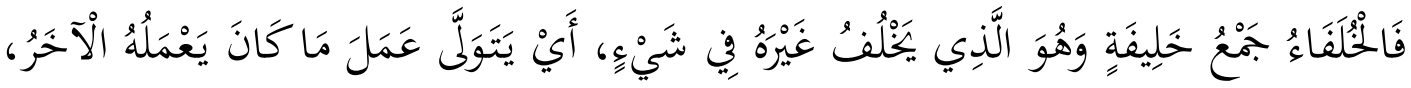

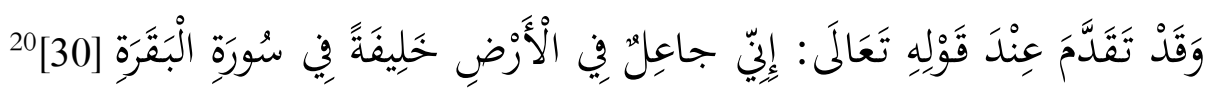

Imam Ibnu 'Āsyūr juga menjelaskan bahwa QS. Al-'Araf (7): 69 merupakan perkataan mumatsil Nabi Nuh kepada kaumnya. Adapun khulafá' yang dimaksud

\footnotetext{
${ }^{19}$ Ibn 'Athiyyah, al-Muharrar al-Wajiz, (tt: CD Room Maktabah Syamelah), juz. 3, h. 60

${ }^{20}$ Ibnu 'Asyūr, al-Tahrìr wa al-Tanwïr (Tūnis: Dār Tūnisiyah, 1984), juz. 8, h. 205
} 
dalam ayat tersebut adalah pemimpin-pemimpin kaum Nabi Nuh. Dengan demikian, khulafá' dalam ayat ini memilki pengertian yang sama dengan term khalifah yang telah dipaparkan sebelumnya.

QS. Al-Naml (27): 62.

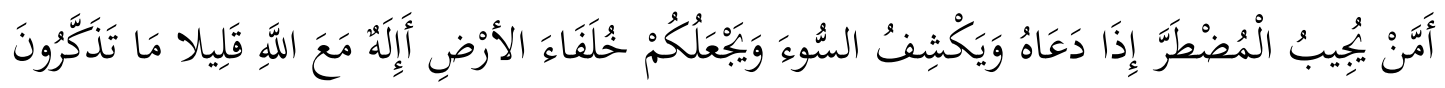

Terjemah: "Siapakah yang memperkenankan (doa) orang yang dalam kesulitan apabila ia berdoa kepada-Nya, dan yang menghilangkan kesusahan dan yang menjadikan kamu (manusia) sebagai khalifah di bumi? Apakah disamping Allah ada tuhan (yang lain)? Amat sedikitlah kamu mengingati (Nya). (QS. Al-Naml (27): 62)

Imam al-Thabari menjelaskan makna khulafă dalam ayat di atas sebagai berikut,

وقوله:(وَيَجَهَلُكُمْ خُحَفَاءَ الأزضِِْ ) يقول: ويستخلف بعد أمرائكم في الأرض منكم خلفاء أحياء

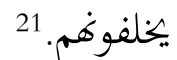

M. Quraish Shihab menyimpulkan bahwa term khalifah dalam Alqur'an digunakan untuk siapa saja yang diberikan kekuasaan mengelola wilayah, baik luas maupun tidak. Selain itu, sang khalifah memiliki potensi untuk melakukan kekeliruan dan kesalahan akibat mengikuti hawa nafsu. Oleh karena itu, Nabi Adam dan Nabi Daud diperingati oleh Allah agar tidak mengikuti hawa nafsu. ${ }^{22}$ Dari paparan sebelumnya, term khalifah dalam bentuk tunggal maupun plural menunjukkan defenisi yang sama. Dengan demikian, term khalifah dimaknai sebagai pemimpin.

\section{Kisah Adam sebagai Pemimpin /Khalifah dalam QS. 2/30-34; Pembacaan Semiotik}

Kisah Adam pada QS. 2/30-34 dimulai dengan ungkapan Tuhan yang hendak menjadikan Adam sebagai khalifah di muka bumi. Tuhan mengutarakan keinginannya tersebut kepada malaikat sehingga terjadi dialog antara Tuhan dan malaikat sebagaimana berikut ini,

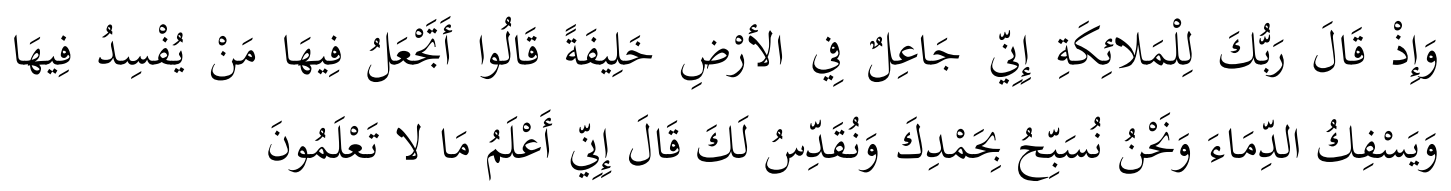

Terjemah: "Ingatlah ketika Tuhanmu berfirman kepada para malaikat: "Sesungguhnya Aku hendak menjadikan seorang khalifah di muka bumi". Mereka berkata: "Mengapa Engkau hendak menjadikan (khalifah) di bumi itu orang yang akan membuat kerusakan padanya dan menumpahkan darah, padahal kami senantiasa bertasbih dengan memuji Engkau dan menyucikan Engkau?"

\footnotetext{
${ }^{21}$ Al-Thabarì, , Jāmi al-Bayān fì Ta'wìl al-Qur'ān, juz. 19, h. 485

${ }^{22}$ M. Quraish Shihab, Membumikan Alqur'an, h. 246
} 
Tuhan berfirman: "Sesungguhnya Aku mengetahui apa yang tidak kamu ketahui".(Q.S Al Baqarah (2): 30)

Pernyataan Allah "Aku hendak menjadikan seorang khalifah di muka bumi" menyiratkan bahwa Allah ingin meminta pandangan atau pendapat dari para malaikat tentang keinginannya itu. Kata khalifah dalam ayat ini merupakan kunci dan topic pembicaraan Tuhan. Oleh karena itu, kata khalifah merupakan representamen (R) atau tanda dari Tuhan. Sebagaimana dipaparkan sebelumnya, bahwa Khalifah merupakan term yang memiliki makna yang setara dengan pemimpin. Dialog Allah dengan malaikat dibuka dengan huruf "iz" yang di-sukun-kan dan diikuti dengan kata kerja lampau qāla (fi'il mādhi). Imam al-Qurtubì menjelaskan bawha huruf iz yang dikuti dengan fi'il mudhāri' memiliki makna telah berlalu, sedangkan huruf iz yang diikuti dengan fi'il mādhi menunjukkan makna mustaqbal. Ada juga pendapat yang mengatakan bahwa iz di sana adalah huruf tambahan (zäidah) namun pendapat ini dibantah oleh Zuraij. ${ }^{23}$ Imam Ibnu Katsir menjelaskan bahwa makna iz dalam ayat di atas adalah wa uzkur ya Muhammad, ${ }^{24}$ (ingatlah wahai Muhammad) ketika Tuhanmu akan berkata kepada malaikat, sesungguhnya Aku hendak menjadikan khalifah di muka bumi. Buya Hamka menjelaskan bahwa makna khalifah dalam ayat tersebut memiliki dua pengertian, pertama Adam sebagai pengganti Adam-Adam terdahulu, ${ }^{25}$ kedua Adam sebagai pengganti Allah untuk mengatur bumi dengan dikarunia akal. ${ }^{26}$

Setelah Allah memberitahukan malaikat tentang keinginannya untuk menciptakan khalifah di muka bumi, para malaikatpun memberikan pandangan mereka dengan mengatakan "apakah Engkau hendak menjadikan khalifah di bumi itu orang yang akan membuat kerusakan padanya dan menumpahkan darah, padahal kami senantiasa bertasbih dengan memuji Engkau dan menyucikan Engkau?”. Jika dibaca dari sudut pandang semiotoka Pierce, respon malaikat di atas merupakan representament $(\mathrm{R})$ karena mengandung atau menyiratkan makna lain. Apa makna lain dari ungkapan malaikat tersebut? Imam Ibnū Katsïr dalam Tafsìr Alqur'ān al'-Adhìm menjelaskan;

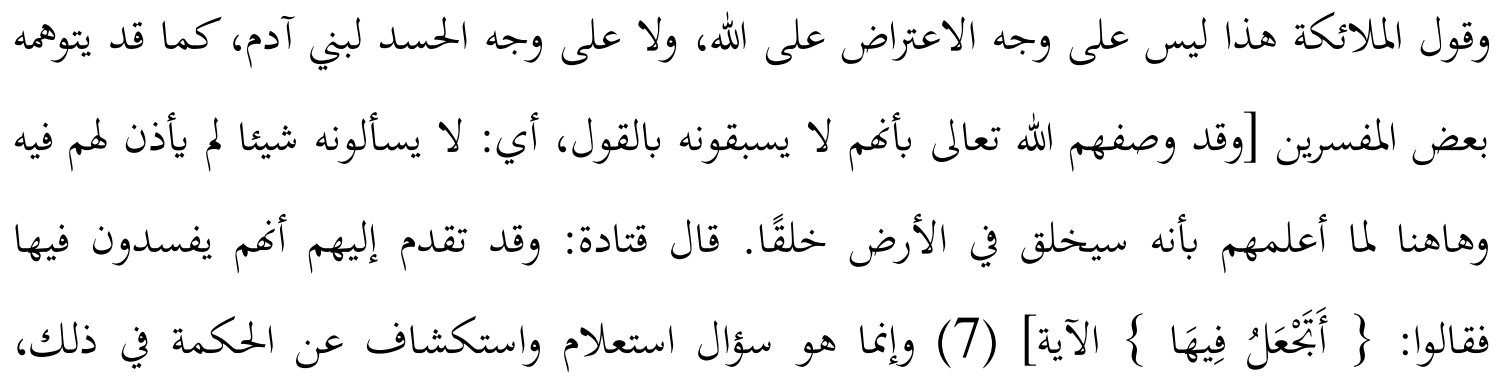

${ }^{23}$ Al-Qurtubi, al-Jāmi' li Ahkām al-Qur'ān (Kairo: Dar al-Kutub al-Mishriyyah, 1286 H/ 1964 M), juz. 1, h. 264

${ }^{24}$ Ibnu Katsir, Tafsìr al-Qur'ān al- ‘Azïm (tt: Dar Thayyibah, 1420 H/ 1999 M), juz. 1, h. 216

${ }^{25}$ Sebuah riwayat yang dikutip oleh Al-Lausi dalam tafsirnya $R \bar{u} h$ al-Ma’āni menyebutkan bahwa sebelum Allah menjadikan Adam nenek kita, sudah ada 30 Adam dan jarak di antara masing-masing Adam adalah 1.000 tahun. Lihat Hamka, Tafsir Al-Azhar, juz. I, h. 168

${ }^{26}$ Hamka, Tafsir Al-Azhar, juz. I, h. 169-170 


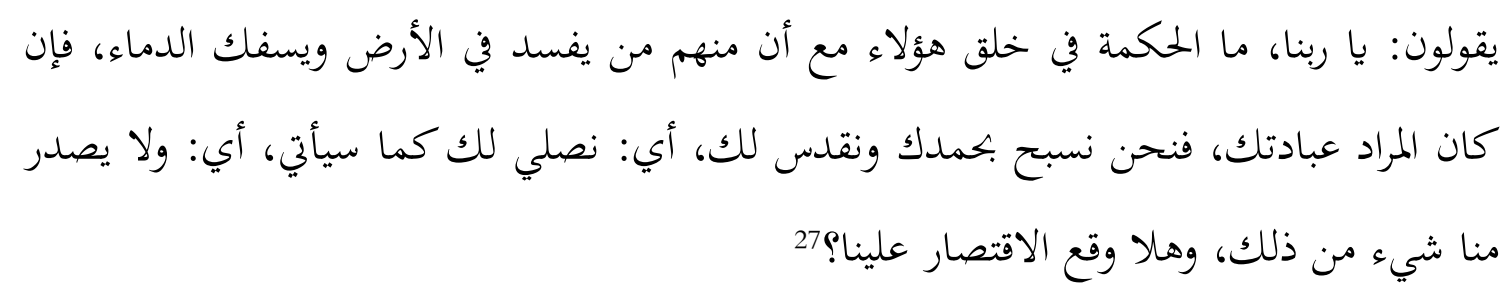

Ibn Katsir menguraikan bahwa ungkapan malaikat "apakah Engkau hendak menjadikan khalifah..." merupakan ungkapan meminta informasi lebih lanjut kepada Tuhan tentang hikmah Tuhan menciptakan khalifah dengan sifat yang suka berbuat kerusakan dan suka menumpahkan darah. Di samping itu, ungkapan "padahal kami senantiasa bertasbih dan memuji-Mu..." dapat dimaknai bahwa malaikat ingin menyatakan protes,

Jika Engkau (Allah) bermaksud ingin disembah, maka kami senantiasa bertasbih dan mensucikanmu, dan perbuatan tercela tersebut tidak pernah kami lakukan. Apakah tidak cukup bagimu? ${ }^{28}$

Ungkapan malaikat, secara tekstual, telihat sebagai ungkapan permintaan informasi lebih lanjut sebenarnya menyiratkan makna protes kenapa tidak kami saja yang dijadikan khalifah yang tidak memiliki sifat buruk (baca: berbuat kerusakan dan melakukan penumpahan darah di muka bumi). Inilah makan Objek (O) dari respon malaikat terhadap keinginan Allah. Hal ini dikarenakan ungkapan malaikat memiliki makna secara simbolik yang menghubungkan antara representament $(\mathrm{R})$ dan objek $(\mathrm{O})$.

Respon malaikat "kami senantiasa bertasbih dan memuji-Mu" menunjukkan bahwa malaikat merasa lebih baik dari pada "man" (sebagaian tafsir menyebutkan Adam) yang ingin Allah jadikan sebagai khalifah dengan sifat yang jelek. Para malaikat mempromosikan diri mereka sebagai sosok hamba yang giat melakukan ibadah spiritual serta mempertanyakan apakah dengan kesalihan spiritual tidak cukup untuk menyandang status khalifah. Melihat makna reprasentement dan objek di atas, diperoleh makna inerpretan (I) dari ungkapan malaikat tersebut, yakni kesalehan spiritual tidak cukup untuk mengantarkan malaikat agar layak menyandang status khalifah (pemimpin).

Mendengar respon dari para malaikat, Tuhan menjawab dengan berfirman "sesungguhnya Aku Maha Mengetahui apa yang tidak kamu ketahui". Apa yang tidak diketahui oleh para malaikat? Ayat selanjutnya menjelaskan ketidaktahuan malaikat tentang hikmah di balik penciptaan (Adam) sebagai khalifah,

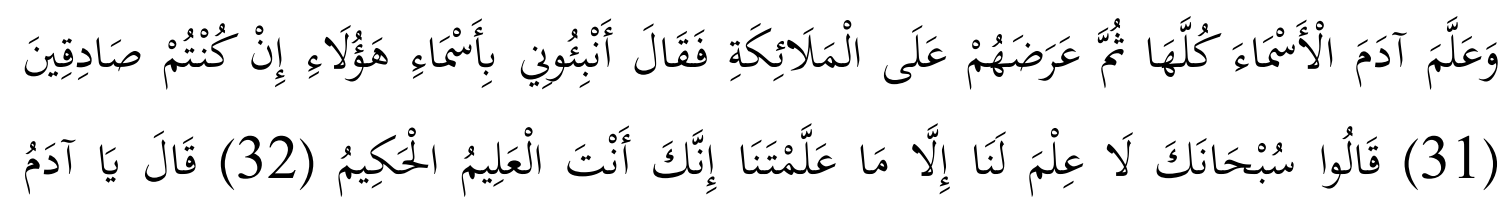

\footnotetext{
${ }^{27}$ Ibnu Katsìr, Tafsìr al-Qur'ān al-'Azìm (tt: Dar Thayyibah, 1420 H/ 1999 M), juz. 1, h. 216

${ }^{28}$ Ibnu Katsìr, Tafsìr al-Qur'ān al- 'Azìm (tt: Dar Thayyibah, 1420 H/ 1999 M), juz. 1, h. 216
} 


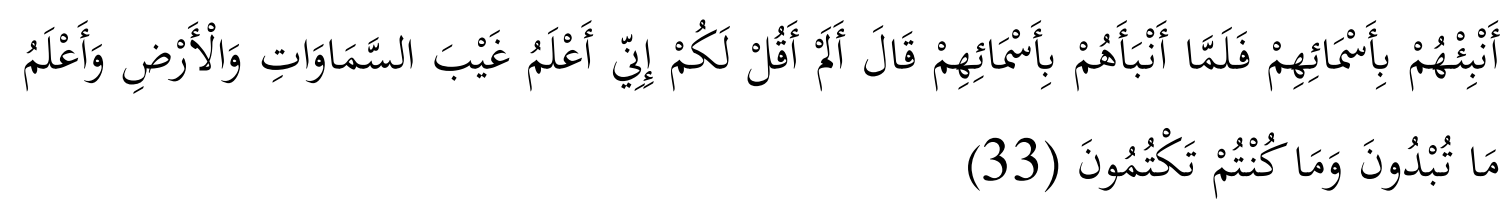

Terjemah: “(31) dan Dia mengajarkan kepada Adam Nama-nama (benda-benda) seluruhnya, kemudian mengemukakannya kepada Para Malaikat lalu berfirman: "Sebutkanlah kepada-Ku nama benda-benda itu jika kamu mamang benar orang-orang yang benar!" (32) mereka menjawab: "Maha suci Engkau, tidak ada yang Kami ketahui selain dari apa yang telah Engkau ajarkan kepada kami; Sesungguhnya Engkaulah yang Maha mengetahui lagi Maha Bijaksana (33) Allah berfirman: "Hai Adam, beritahukanlah kepada mereka Nama-nama benda ini." Maka setelah diberitahukannya kepada mereka Nama-nama benda itu, Allah berfirman: "Bukankah sudah Ku katakan kepadamu, bahwa Sesungguhnya aku mengetahui rahasia langit dan bumi dan mengetahui apa yang kamu lahirkan dan apa yang kamu sembunyikan?” (QS. Al-Baqarah (2): 31-33)

Pada ayat sebelumnya, para malaikat merespon rencana Allah dengan maksud menanyakan apa hikmah penciptaan seorang khalifah kepada Allah sebagaimana dijelaskan oleh imam Ibnu Katsï. Ibnu Katsir menjelaksan bahwa Adam memiliki kemuliaan yang tidak dimiliki oleh malaikat yaitu berupa pengetahuan (asmā') tentang seluruh nama benda-benda. ${ }^{29}$ Allah menunjukkan kepada malaikat akan kemuliaan Adam bahwa Adam memiliki pengetahuan yang luas. Allah mengajarkan Adam tentang seluruh nama (asmā') benda-benda yang tidak diajarkan kepada malaikat. Dengan demikian, pengetahuan adalah sifat iconic yang mengantarkan Adam layak menjadi khalifah. Ini merupakan makna Objek (O) dari term khalifah (R) dalam

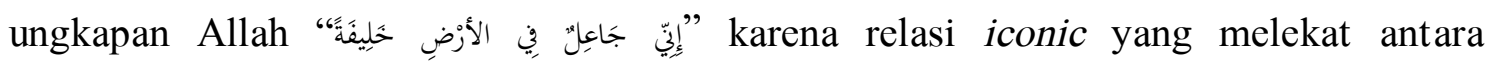
Respresentamen dan Objek. Dari hubungan term khalifah sebagai representament (R) dan asmā sebagai objek (O), kita dapat merumuskan makna interpretan (I) bahwa kepemimpinan hanya berhak diberikan kepada orang yang memiliki kapasitas dan pengetahuan. Hal ini selaras dengan kelayakan Adam menyandang status khalifah (pemimpin) karena karunia pengetahuan. Lalu Allah menutup bagian ini dengan ungkapan yang bermakna serupa dengan QS. 2/30 di mana Allah kembali menyatakan superioritas-Nya bahwa Dia-lah Tuhan yang Maha Mengetahui, sedangkan para malaikat tidak mengetahui.

Setelah Allah memaparkan alasan pemilihan Adam sebagai khalifah, Allah kembali berdialog dengan malaikat dan iblis. Allah memerintahkan mereka untuk bersujud kepada Adam. Namun, malaikat dan iblis menunjukkan sikap yang berbeda dalam merespon perintah tersebut. Malaikat memilih taat kepada perintah Allah untuk bersujud kepada Adam karena malaikat ditetapkan sebagai sosok yang selalu taat kepada perintah Allah dan menjahi larangan-Nya. ${ }^{30}$ Sementara itu, Iblis memilih

\footnotetext{
${ }^{29}$ Ibnu Katsïr, Tafsìr al-Qur'ān al-‘Azïm, juz. 1, h. 222

${ }^{30}$ Lihat QS. Al-Tahrim ayat 6
} 
membangkang atau enggan bersujud kepada Adam sebagaimana dikisahkan pada ayat berikut ini;

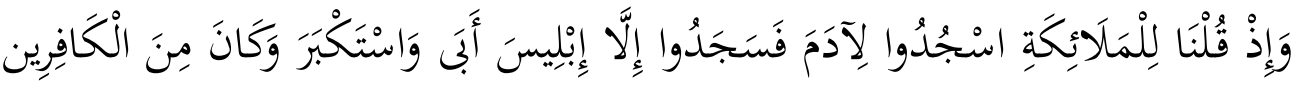

Terjemah: "Dan (ingatlah) tatkala Kami berkata kepada malaikat: Sujudlah kamu kepada Adam! Maka sujudlah mereka, kecuali iblis enggan dia dan menyombong, karena dia adalah termasuk golongan makhluk yang kafir. (QS. Al-Baqarah: 34)

Enggan dan tidak mau untuk bersujud kepada Adam adalah jalan yang dipilih oleh Iblis. Keengganan Iblis untuk bersujud kepada Adam bukan tanpa alasan. Aksi iblis dapat diinterpretasi sebagai tanda (representaemnt) dalam semiotika Pierce. Penolakan iblis bersujud kepada Adam dilukiskan Alqur'an dalam QS. Al-A'raf: 11-13

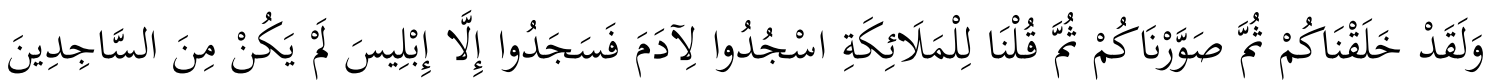

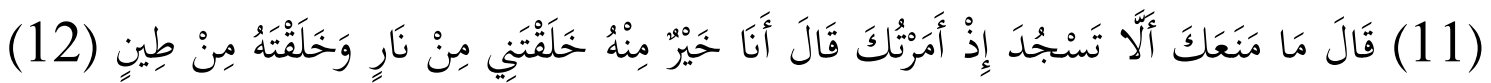

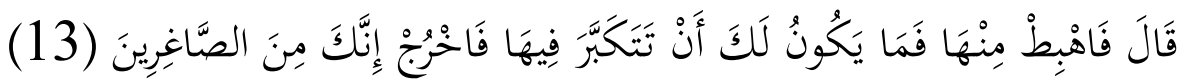

Terjemah: "11. Sesungguhnya Kami telah menciptakan kamu (Adam), lalu Kami bentuk tubuhmu, kemudian Kami katakan kepada para malaikat: "Bersujudlah kamu kepada Adam", maka merekapun bersujud kecuali iblis. Dia tidak termasuk mereka yang bersujud. 12. Allah berfirman: "Apakah yang menghalangimu untuk bersujud (kepada Adam) di waktu Aku menyuruhmu?" Menjawab iblis "Saya lebih baik daripadanya: Engkau ciptakan saya dari api sedang dia Engkau ciptakan dari tanah". 13. Allah berfirman: "Turunlah kamu dari surga itu; karena kamu sepatutnya menyombongkan diri di dalamnya, maka keluarlah, sesungguhnya kamu termasuk orang-orang yang hina". (QS. Al-A'raf (7): 11-13)

Tuhan menanyakan alasan mengapa iblis enggan bersujud kepada Adam. Dengan pongah dan sombong, Iblis mengatakan bahwa ia tidak ingin sujud kepada Adam lantaran Iblis merasa lebih baik dari Adam. Iblis dengan angkuh menyatakan bahwa mereka diciptakan dari api, sementara Adam diciptakan dari tanah. Ungkapan iblis "Kau cipakan aku dari api sementara Kau ciptakan dia dari tanah" merupakan objek (O) dari representamen (keengganan Iblis untuk bersujud kepada Adam), karena memiliki hubungan iconis berupa ungkapan verbal ${ }^{31}$ Iblis tentang faktor yang menyebabkan ia tidak mau sujud kepada Adam.

Sikap Iblis tersebut merupakan buah dari anggapan Iblis bahwa Adam tidak lebih baik dari mereka. Dengan kata lain, Iblis beranggapan bahwa seharusnya Adamlah

${ }^{31}$ Representament-objek dalam teori semiotic Pierce dapat berupa hubungan iconic yang meliputi sisi voisual, atau bisa ungkapan verbal. Representament-objek juga bisa diperoleh dari hubungan indexial atau symbolic. Penjelasan lebih rinci rujuk Wildan Taufiq, Semiotika untuk Kajian Sastra dan Alqur'an, (Bnadung: Yrama Widya, 2016), h.30-38 
yang bersujud kepada mereka. Membaca hubungan antara sikap enggan Iblis untuk sujud (R) dan anggapan Iblis karena mereka lebih baik daripada Adam (O), adalah bukti yang cukup untuk mengantarkan kita kepada interpetasi (I) bahwa Iblis hendak menyangsikan dirinyalah yang lebih layak menjadi khalifah daripada Adam. Namun argumen kemuliaan asal-usul (nasab, keturunan) yang diajukan oleh iblis (lihat. Q. 7/12) tidak cukup untuk menjadikan Iblis layak menyandang gelar khalifah (pemimpin). Justru sebaliknya, kesombongan dan kepongahan iblis akan asal-usul mereka bukannya menjadikan mereka sebagai khalifah, melaikan membawa mereka kepada kehinaan sehingga iblis diusir dari syurga dan mendapat azab berupa kekal dalam api neraka. Menurut penulis, asal-usul dalam hali ini dapat disejajarkan dengan keturunan nasab sehingga dapat dipahami bahwa faktor nasab atau keturunan bukan merupakan standar untuk menjadi pemimpin.

\section{Makna Filosofis Kisah Penciptaan Adam sebagai Khalifah}

Setelah membaca kisah penciptaan Adam sebagai khalifah dalam QS. AlBaqarah (2): 30-34 dari perspektif Semiotika Pierce, setidaknya ada beberapa pandangan esensial Alqur'an tentang pemimpin (khalifah). Jika kita cermati lebih lanjut, maka kritik-kritik Alqur'an terkait diskursus kepemimpinan sangat layak untuk dikemukakan kembali, karena sangat aktual dan kontekstual. Untuk itu, penulis merumuskan setidaknya ada tiga makna filosofis yang terkandung dalam kisah di atas dalam kaitannya dengan diskursus kepemimpinan. Apa saja makna filosofis dari QS. Al-Baqarah: 30-34 terkait diskursus kepemimpinan?

\section{Menjadi khalifah bukan tentang saleh spiritual}

Dalam kepemimpinan, kesalehan spiritual memang penting, namun bukanlah satu-sat unya jaminan untuk menjadi pemimpin. Mengacu kepada kepemimpinan nabinabi dalam Alqur'an, tidak dapat dipungkiri bahwa kesalehan juga merupakan syarat penting, namun masih ada syarat yang lebih penting untuk menjadi pemimpin. Dalam kisah Adam sebagai khalifah, Alqur'an menerangkan hal ini dengan gamblang. Alqur'an bahkan mengkritik kepemimpinan yang hanya membanggakan kesalehan spiritual. Dari mana didapat kesimpulan demikian? Kesimpulan ini dapat dilacak dari dialog malaikat dengan Tuhan dalam QS. Al-Baqarah ayat 30 di mana malaikat sedikit heran terhadap kehendak Allah untuk menjadikan seorang khalifah di bumi dengan argumen bahwa mereka (malaikat) mempunyai spiritualitas yang tinggi. Malaikat mendaku sebagai hamba yang selalu beribadah kepada Allah, sementara khalifah yang hendak dijaidkan Allah mempunyai sifat buruk, yakni suka berbuat kerusakan dan menumpahkan darah. Kisah ini dijelaskan oleh Ibn Katsïr berikut, 


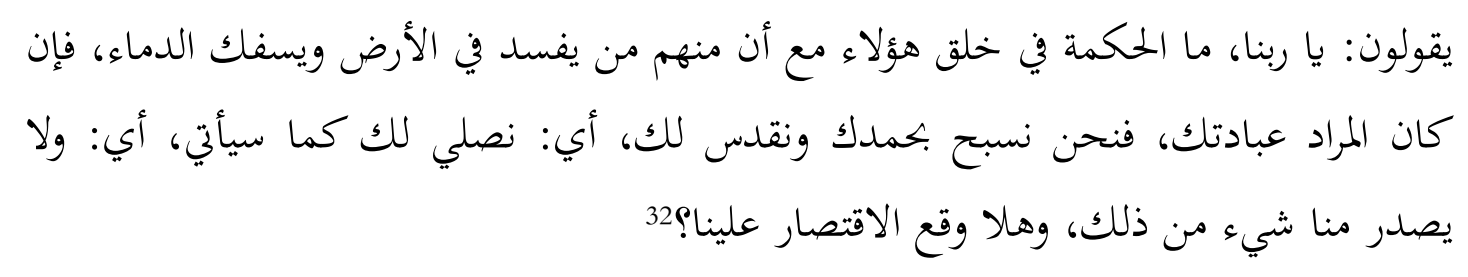

Respon malaikat secara jelas memperlihatkan bagaimana mereka membanggakan keshalihan spiritualitas mereka. Mereka menyangka bahwa kesalihan spiritual saja dapat menjadikan mereka sebagai khalifah. Namun, hal itu tidak membuat mereka layak untuk menjadi khalifah. Atas dasar itu, kesalehan spiritual saja tidak menjadi patokan atau standar untuk menjadi pemimpin. Dengan kata lain, iman (spiritual) tanpa ilmu (kapasitas) memimpin tidak cukup untuk mengemban amanat kepemimpinan. Iman (kesalehan spiritual) harus dibarengi dengan ilmu pengetahuan untuk menopang kepemimpinan menjadi kokoh dan melahirkan peradaban.

\section{Pemimpin tidak dipandang dari faktor ketururnan}

Nasab atau keturunan seringkali dijadikan sebagai tolak ukur untuk menjadi pemimpin. Sejarah mencatat bahwa kerajaan dan dinasti-dinasti menerapkan sistem keturunan dalam pemerintahan. Sang ayah yang berkedudukan sebagai raja akan memberikan estapet kepemimpinannya kepada keturunanannya apakah itu anaknya atau saudaranya. Yang jelas kepada yang masih memiliki hubungan darah (biologis) dengannya. Alqur'an, melalui kisah penciptaan Adam sebagai khalifah, mengkritik pandangan tersebut bahwa faktor nasab dan keturunan bukanlah patokan untuk menjadi khalifah atau pemimpin. Karena iblis juga telah membanggakan asal-usulnya dan menganggap asal-usulnya lebih baik dari pada Adam sehingga iblis memandang bahwa mereka lebih baik daripada Adam. Atau makna implisit dari pengakuan itu adalah Iblis merasa lebih berhak menjadi khalifah dibangdingkan Adam. Kisah ini sebagaimana dijelaskan terdahulu dalam QS. Al-Baqarah 34 dan al-A'raf 12.

Iblis menegaskan bahwa mereka diciptakan Tuhan dari api. Sementara Adam diciptakan dari tanah. Iblis menganggap asal-usul penciptaan mereka lebih baik dan mulia daripada Adam. Oleh karena itu, Iblis merasa lebih berhak untuk mendapatkan posisi khalifah dan mendapat sujud (pengakuan) dari Adam. Asal-usul dalam hal ini dapat dimaknai sebagai nasab atau keturunan atau nenek moyang. Faktor keturunan tidak mampu menjadikan iblis layak untuk menyandang status khalifah. Lewat kisah ini, menurut penulis Alqur'an sebenarnya mengkritik model kepemimpinan yang didasari hanya oleh faktor keturunan atau nasab. Syarat menjadi khalifah bukanlah berasal dari keturunan (nasab) raja, presiden, gebernur dan lain sebagainya.

Sampai di sini mungkin masih ada sanggahan, bagaimana dengan kisah nabi Ibrahim pada QS. Al-Baqarah ayat 124? Dalam kisah tersebut, nabi Ibrahim memang meminta kepada Allah agar keturunannya dijadikan sebagai imām (pemimpin). Kata

\footnotetext{
${ }^{32}$ Ibnu Katsìr, Tafsìr al-Qur'ān al- ‘Azìm, juz. 1, h. 216
} 
“imām”, menurut Quraish Shihab, adalah padanan dari kata khalifah. ${ }^{33}$ Namun dalam kisah tersebut Allah memberikan persyaratan "janji-Ku tidak diperoleh orang-orang yang berbuat zalim". Menurut Quraish Shihab, kezaliman adalah lawan dari keadilan. Dengan demikian ayat ini menunjukkan bahwa anugerah imam atau pemimpin hanya diberikan Allah kepada orang yang Adil. ${ }^{34}$ Adil merupakan kualitas sang pemimpin. Jadi dalam kisah Ibrahim juga disyaratakan kualitas adil untuk bisa menjadi imam dari keturunan Ibrahim. Artinya tidak semata-mata aspek keturunan (nasab). Di samping itu, Ismail juga memiliki asmā' atau pentehuan dan kapasitas untuk memimpin sebagaimana Adam.

\section{Pengetahuan (Asmā') adalah faktor utama untuk menjadi pemimpin}

Menjadi pemimpin adalah amanat yang berat. Oleh karena itu, tidak semua orang dapat mengembannya. Hanya orang-orang dengan kriteria khususlah yang pantas dan mampu memikulnya. Malaikat dan Iblis menjadi bukti bahwa tidak semua makhluk dapat menjadi khalifah. Mengapa malaikat dan iblis tidak dapat menjadi khalifah? Ibnu Katsïr menjelaskan bahwa ada faktor yang tidak dimiliki oleh malaikat dan iblis untuk menjadi khalifah. Kemuliaan yang dimaksud adalah berupa pengetahuan atau (asmā') sebagaimana dalam QS. Al-Baqarah ayat 31. Ibnu Katsï menuliskan hal ini dalam tafsirnya sebagai beikut,

$$
\text { هذا مقام ذكر الله تعالى فيه شرف آدم على الملائكة، بما اختصه به من عِلم أسماء كلّ شيء وهذاء كان }
$$

Menurut Ibnu Katsīr, kemuliaan yang dimiliki Adam adalah menguasai asmā'. Dalam riwayat Ibnu Abbas disebutkan bahwa yang dimaksud asmā' adalah nama-nama yang diketahui oleh manusia meliputi manusia, binatang, langit, bumi, hewan, unta dan lain-lain. Senada dengan itu, Ibnu Mujāhid menjelaskan bahwa yang dimaksud dengan asmā' adalah nama binatang, burung dan segala sesuatu. ${ }^{36}$ Senada dengan Ibnu Katsìr, Hamka juga menyatakan bahwa kelayakan Adam menjadi khalifah adalah karena karunia pengetahuan yang luas yang diberikan Allah kepadanya di mana karunia itu tidak diberikan kepada malaikat dan Iblis. ${ }^{37}$ Pengetahuan yang diwakili term asma $\bar{a}$,

\footnotetext{
${ }^{33}$ M. Quraish Shihab, Membumikan Alqur'an, h. 253-255

${ }^{34}$ M. Quraish Shihab, Membumikan Alqur'an, h. 255

${ }^{35}$ Ibnu Katsìr, Tafsìr al-Qur'ān al- 'Azìm, juz. 1, h. 222

${ }^{36}$ Ibnu Katsìr, Tafsìr al-Qur'ān al-'Azìm, h. 223

${ }^{37}$ Hamka, Tafsir Al-Azhar, juz. I, hlm. 172
} 
dalam ayat 31 jika kita kaitkan dengan kepemimpinan, maka maknanya bisa saja melebar seperti pengetahuan tentang kepemimpinan itu sendiri.

Atas dasar itu, kita dapat menyatakan dengan tegas bahwa kepemimpinan yang ideal menurut Alqur'an dalam kisah Adam adalah kepemimpinan yang berdasarkan asmā' atau pengetahuan, bukan hanya dipandang dari kesalehan spiritual semata atau nasab keturunan. Karena memimpin membutuhkan pengetahuan dan konsep agar memberikan kemaslahatan bagi rakyat yang dipimpin. Disamping itu, memiliki kapasitas pengetahuan atau cakrawala yang luas sangat dibutuhkan oleh pemimpin untuk mengatur masyarakatnya dan untuk mengahadapi problem-problem dalam pemerintahannya. Perlu dicatat bahwa kepemimpinan dalam ayat ini adalah bersifat general, tidak spesifik kepemimpinan politik. Namun bisa saja dibawa konsep ini dalam pandangan kepemimpinan politik dengan pertimbangan bahwa segala bentuk kepemimpinan memerlukan pengetahuan.

Selain dikaruniai pengetahuan (asmā), Adam juga dikaruniai iman dan kesolehan. Ketika Adam dan isterinya melakukan kesalahan (Q. 2/37), mereka langsung bertaubat kepada Allah. Dengan demikian, Adam layak dijadikan sebagai khalifah di bumi dengan pertimbangan dua faktor, yakni pengetahuan dan iman. Dua komponen ini hendaknya berjalan dan selaras dan bersamaan dalam diri pemimpin. Amanat kepemimpinan harus diserahkan kepada pribadi yang mempunyai kapasitas dan pengetahuan untuk memimpin. Pengetahuan dan spiritual harus berjalan beriringan dalam diri pemimpin, karena menurut Quraish Shihab ilmu tanpa iman bagaikan senjata di tangan penjahat atau di tangan pencuri ${ }^{38}$ Artinya, iman menuntun pemimpin menggunakan wewenangannya sebagaimana mestinya.

Demikian interpretasi semiotik QS. 2/30-34 yang menguak pandangan tentang kepemimpinan. Interpretasi lain bisa saja dikembangkan dari kisah Adam di atas, karena interpretan (intepretasi) dalam teori Semiotik Pierce tidak bersifat tunggal dan bisa saja terus berkembang atau melahirkan makna baru.

\section{Penutup}

Dari sudut pandang Semiotika Pierce, QS. Al-Baqarah: 2/30-34 setidaknya memberikan beberapa informasi penting mengenai isu kepemimpinan. Pertama, kesalihan spiritual bukanlah faktor utama untuk meduduki status khalifah . Hal ini dapat dikeathui dari ungkapan malaikat yang mempromosikan diri mereka sebagai ahli ibadah ketika merespon rencana Tuhan untuk menjadikan seorang khalifah di muka bumi. Namun saleh spiritual (ahli dalam beribadah) tidak mengantarkan mereka pada status khalifah (pemimpin). Kedua, Alqur'an menolak mentah-mentah faktor keturunan sebagai tolak ukur menjadi pemimpin. Makna ini diperoleh dari keengganan Iblis untuk bersujud kepada Adam karena mereka merasa asal-usul penciptaan mereka lebih baik dari pada Adam. Mereka diciptakan dari api, sementara Adam dari tanah. 302

${ }^{38}$ M. Quraish Shihab, Lentera Qur'an; Kisah dan Hikmah Kehidupan (Bandung: Miza, 2014), h. 
Namun, khalifah bukanlah tentang asal-usul atau keturnan sehingga iblispun tidak layak menjadi khalifah. Ketiga, pengetahuan atau konsep adalah syarat mutlak menjadi pemimpin. Dalam QS. Al-Baqarah 30-34, Allah lebih memilih Adam sebagai khalifah daripada malaikat dan iblis lantaran Adam dikaruniai pengetahuan (asmā'), sedangkan malaikat dan iblis tidak dikarunia asmā.

\section{DAFTAR PUSTAKA}

Al-Bāqi, Muhammad Fuād 'Abd. Mu’jam Mufahras li Alfādz al-Qur'ān. Indonesia: Maktabah Dakhlan. t.th.

Al-Misri. Lisān al-'Arab. Beirut: Dar al-Shadr. 1992.

Al-Qurtubi. al-Jāmi’ li Ahkām al-Qur'ān. Kairo: Dār al-Kutub al-Mishriyyah. 1286 H/ $1964 \mathrm{M}$.

Al-Tthabari. Jāmi al-Bayān fī Ta'wìl al-Qur'ān. Beirut: Muassasah al-Risalah, 1420 H/ $2000 \mathrm{M}$.

'Asyūr, Ibnu. al-Tahrī̄ wa al-Tanwïr. Tunis: Dar Tunisiyah. 1984.

Hamka. Tafsir al-Aazhar. Jakarta: Pustaka Panjimas. 1982.

Ibn 'Athiyyah, al-Muharrar al-Wajīz diakses dari CD Room Maktabah Syamelah.

Ibnu Katsī, Tafsìr al-Qur'ān al-'Azìm. tt: Dar Thayyibah. 1420 H/ 1999 M.

Jalaludin al-Mahalli dan Jalaluddin al-Suyuthi. Tafsìr al-Jalālain. terj. Bahrun

Abubakar (Banudng: Sinar Baru Algensindo. cet. II 2004.

Jindan, Khalid Ibrahim. Teori Pemerintahan Islam Menurut Ibnu Taimiyah. Jakarta: Rineka Cipta. 1994.

Raghib al-Ashfihani, Mu'jam Mufradāt Alqur'an, (tt: CD Room Maushu'ah)

Rahim, Abd. "Khilafah dan Khalifah dalam Alqur'an" dalam Hunafa; Jurnal Studi Islamika, vol. 9, no. 1. juni 2012.

Shihab, M. Quraish. Membumikan Alqur'an; Fungsi dan Peran Wahyu dalam Kehidupan Masyarakat. Bandung: Mizan. cet. III 2009.

Shihab, M. Quraish. Lentera Qur'an; Kisah dan Hikmah Kehidupan. Bandung: Mizan. 2014.

Taufiq, Wildan. Semiotika untuk Kajian Sastra dan Alqur'an. Bnadung: Yrama Widya. 2016.

Wijaya, Yahya. "Kepemimpinan Yesus sebagai Acuan Bagi Kepemimpinan Gereja Masa Kini" dalam Jurnal Jaffray, vol. 2. no. 16. 2018.

Zeost, Aart Van. Semiotika; tentang Tanda- Cara Kerjanya dan Apa yang Kita Lakukan dengannya. Terj. Ani Soekowati. Jakarta: Yayasan Sumber Agung. 1993. 